\title{
The in-store shopping experience: A comparative study of supermarket and clothing store customers
}

\author{
N.S. Terblanche* \\ Department of Business Management, University of Stellenbosch, \\ Stellenbosch 7600, Republic of South Africa \\ nst@sun.ac.za \\ C. Boshoff \\ Department of Business Management, University of Port Elizabeth, \\ PO Box 1600, Port Elizabeth 6000, Republic of South Africa \\ Christo.Boshoff@upe.ac.za
}

Received July 2004

\begin{abstract}
Various developments continually pressurise retailers to find new and innovative ways to differentiate themselves from competitors and adapt to ever-changing and accelerating environmental circumstances. Positioning based on customers' in-store shopping experience (ISE) offers retailers an alternative means of differentiation and is achieved by providing a superior in-store shopping experience. The ISE instrument that has been developed to measure customers' in store shopping experience is used in this study to compare the in-store shopping experiences of customers of two diverse retailing environments (supermarkets versus clothing retailers) by assessing its impact on customer retention. A proposition is formulated and the findings reported. The implications of ISE and customer retention for retail managers are also dealt with
\end{abstract}

*To whom all correspondence should be addressed.

\section{Introduction}

During the past two decades retailers have had to deal with increasingly more sophisticated and demanding customers, new and often unanticipated competition from both domestic and foreign sources and a wave of new technological advances. These and other developments exert continuous pressure on retailers to find new and innovative ways to differentiate themselves from competitors and adapt to ever-changing and accelerating environmental circumstances (Dabholkar, Thorpe \& Rentz, 1996:3). Retailers' attempts to differentiate themselves vary from efforts to compete on superior service quality to loyalty schemes. The re-emergence of relationship marketing and the afore-mentioned rivalry in the retail market environment have, especially since the 1990s, also led to a renewed emphasis on customer retention and loyalty by retailers. The large number of customer loyalty schemes operated by retailers is evidence of this challenging situation. Most of the differentiation attempts have, however, produced limited success (Egan, 1999; Sopanen, 1996; Berry 1986; Hummel \& Savitt, 1988; Reichheld \& Sasser, 1990; Dabholkar et al., 1996).

This study reconsiders the differentiating dilemma that retailers face and in particular its relationship with customer retention and loyalty.

\section{Differentiation in the modern retailing environment}

We approached the possibility of a new differentiation angle for retailers on the basis of what consumers want to experience from the moment they enter the store until they leave the store. When asked to discuss what is important to them when they are out shopping most of our focus group participants refer to their in-store experiences and end states. A closer analysis of their responses reveals that their in-store experiences are largely shaped by what can be termed store image and service-quality related considerations. Thus, in line with Mazursky and Jacoby (1985), we argue that store image represents a customer's attitude towards a retailer and will be determined by his or her assessment of all merchandise-related aspects encountered during the shopping experience, all service-related aspects related to the shopping experience, as well as other in-store factors that contribute to the general pleasantness of the shopping experience. In other words, we suggest that the in-store shopping experience is a multi-dimensional construct and argue that multiple in-store experiences (at the transaction level) over time 'cascade' to an overall or cumulative assessment we term in-store shopping experience.

Positioning based on customers' in-store shopping experience offers retailers an alternative means of differentiation and is achieved by providing a superior instore shopping experience. We thus confine and operationalise the concept in-store shopping experience as 
all merchandise, service and other in-store factors that contribute to the customer's assessment of the shopping experience and that fall within the managerial control of retail managers. The study is thus limited to those variables that a retail store can manage and influence and therefore excludes factors related to the customer's situation which the retailer has no control over.

\section{The in-store shopping experience construct}

Dabholkar et al. (1996) proposed an instrument based on SERVQUAL, which they suggest, measures service quality in a retailing environment and also captures additional dimensions of retail service quality unique to the retail environment. Although the Dabholkar et al. (1996) study contributed to a greater understanding of service quality in a retail environment, it was criticised, amongst other things, because it failed to investigate the relationship between customer perceptions of the quality of the products a retailer carries and customer perceptions of the service quality provided by the retailer (Finn \& Kayandé, 1997:2). A study by Vásquez, Rodriques-del Bosque, Díaz and Ruiz in 2001 also attempted to develop an instrument that could capture more of the dimensions that are unique in a retail setting where a mix of goods and services is offered. They (Vásquez et al., 2001) were, however, unable to overcome the limitations of Dabholkar et al.'s (1996) contribution.

It was earlier argued that it is largely the store shopping experience itself which determines customer perceptions of a store (Kerin, Jain \& Howard, 1992: 394). This school of thought maintains that, from a measurement and management perspective, a comprehensive instrument that captures all the dimensions of a shopping experience should be the focus as opposed to just one dimension such as service quality. In other words, in a retail environment where a mix of goods and services is offered, the comprehensive approach would be preferable. When considered in this way service quality, for instance, is only one component of the consumer's in-store shopping experience, as are several other components. If only one component of the in-store shopping experience is considered in isolation, it may be detrimental to our understanding of customers' experiences, and this in turn could lead to strategies that either overemphasize or neglect the importance of one or more in-store shopping experience components.

Based on the work of Dabholkar et al. (1996) and Vásquez et al. (2001) we developed a measuring instrument that overcomes the limitations of earlier attempts to measure the perceptions of the in-store shopping experiences of customers. After initial focus group interviews and a rigorous scale development process involving more than 11 000 respondents from 31 stores in five retail industries we conclude that the in-store shopping experience of customers is a five-dimensional construct as depicted in Figure 1 (Terblanche \& Boshoff, 2003).

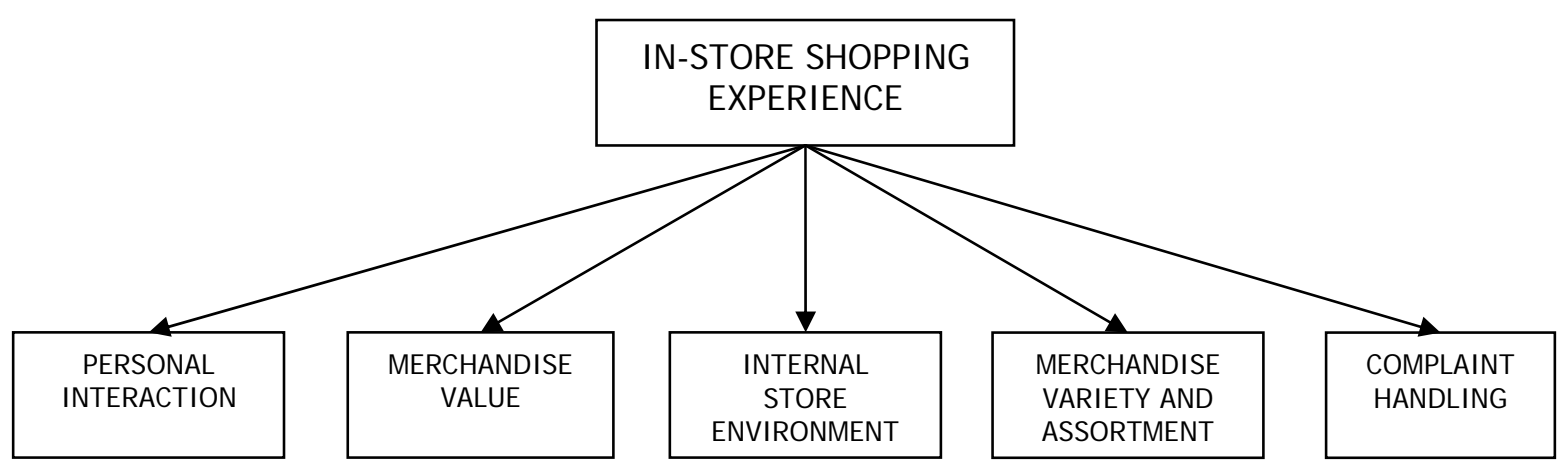

Figure 1: The structure of the in-store shopping experience

The ISE instrument is, to a large extent, the combination of Servqual and store image dimensions which are important to customers in their in-store shopping experiences. Store image largely consists of the following three general factors: merchandise-related aspects, service-related aspects, and pleasantness of shopping at a store (Mazursky \& Jacoby, 1985). All three of these aspects are captured in the five underlying dimensions of the ISE construct (Figure 1) and all five will impact on beneficial outcomes such as cumulative customer satisfaction and customer retention/loyalty at retail level.

\section{Personal interaction}

Personal interaction is operationalised as all face-to-face interaction between retail employees and customers and consists of the responsiveness, assurance and empathy dimensions captured by the SERVQUAL instrument (Parasuraman, Zeithaml \& Berry, 1988).

\section{Merchandise value}

A number of researchers have emphasised the importance of the quality of products (merchandise) in consumers' perceptions, their evaluation of retailers and their image of retail stores (Dabholkar et al., 1994:4; Sirohi, Mclaughlin \& Wittink, 1998:240). Price has an important bearing on customer satisfaction primarily because customer satisfaction is the result of a customer's perception of the value received compared to the price paid (Anderson, Fornell \& Lehmann, 1994; Hallowell, 1996:26; Athanasspoulos, 2000:192; Cronin, Brady \& Hult, 2000). 
During the extensive scale development process utilised in this study the items measuring product quality and price loaded on a single factor (implying that they are elements of a single construct) during the exploratory factor analysis phase of the data analysis and thus were subsequently named 'merchandise value'.

\section{Internal store environment}

Internal store environment refers to all those elements that contribute to a pleasant shopping atmosphere such as shop layout, aisles that make it easy to move around, store cleanliness, well-spaced product displays, and attractive décor. The retail literature suggests that customers value the convenience that physical aspects, such as store layout, offer (Gutman \& Alden, 1985; Hummel \& Savitt, 1988; Mazursky \& Jacoby, 1985; Oliver, 1981). Dabholkar et al. (1996:7) also found empirical support for the contention that shop layout contributes to customers' shopping convenience and therefore a satisfactory shopping experience. Insights and evidence from the environmental psychology literature support the notion that physical surroundings can influence the attitudes as well as the behaviours of consumers in a retail store (Donovan \& Rossiter, 1982; Darden, Erdem \& Darden, 1983; Ridgway, Dawson \& Bloch, 1989). Tangible store attributes can also be seen as the 'means' by which a consumer is able to achieve a desired 'end', such as a satisfying in-store shopping experience (Kerin et al., 1992:381). Sirohi, Mclaughlin and Wittink (1998:237), for instance, found that good facility design (overall appearance of the shop, cleanliness, wide aisles, departments in appropriate places, and well-marked aisle directions) leads to enhanced perceptions of overall merchandise quality. The physical nature of a store, its layout, appearance and physical presentation, thus play a major supporting role in the retail product offering (Greenley \& Shipley, 1988:52).

\section{Merchandise variety and assortment}

Merchandise variety and assortment are components of the conventional retail marketing mix (Hasty \& Reardon, 1997:11). Products probably present the most complex expectation customers have of retail shops, because they expect to find in a store a variety or a selection of different kinds of products that are consistent with their personal shopping intentions and preferences (Davidson, Sweeney \& Stampfl, 1988:141). Assortment is closely related to variety, as it is the range of choice offered within a category of products. Consumers, therefore, expect to find not only a variety of products, but also an assortment of different colours, brands, styles, models and sizes for each product line. In a recent study, it was found that the variety and assortment dimension may consist of three components: assortment size, attribute dispersion, and attribute association (Van Herpen \& Pieters, 2000: 2). Merchandise variety and the depth of assortment will, to a large extent, be influenced by the image the retailer wishes to project.

\section{Complaint handling}

As part of the initial ISE scale development process, we tested a number of store policies to ensure that those elements that are influenced by a store's responsiveness to the customer's needs, are captured. The potential store policy elements considered were the return or exchange of purchases, shopping hours, payment options available, and a system or process to deal with customer enquiries and/or complaints (Westbrook, 1981; Mazursky \& Jacoby, 1985; Dickson \& MacLachlan, 1990; Dickson \& Albaum, 1977). Our analyses, however, revealed that the only 'store policy' items that emerged as a separate dimension of the in-store shopping experience were items referring to complaint handling. Complaint handling was thus identified as a dimension of the in-store shopping experience.

To summarise: we believe that the in-store shopping experience is a multi-dimensional construct and that the ISE instrument captures the following five dimensions of the instore shopping experience, namely: merchandise value, internal store environment, personal interaction, merchandise variety and assortment, and complaint handling. All the dimensions of the ISE instrument had Alpha Cronbach values in excess of 0,7 whilst the entire instrument returned an Alpha Cronbach value of 0,951. The psychometric properties of the ISE instrument are compelling in terms of its unidimensionality, with-in method convergent validity, cross-validation of dimensions in a cross-validation sample, and its nomological validity (Terblanche \& Boshoff, 2003).

We have focused our investigation on the measurement and management of the in-store shopping experience (ISE) and refer to all interactions and experiences the customer goes through from entering to leaving the shop door. The development of the ISE instrument was limited to in-store retailing which, by definition, excludes retail formats such as catalogue and internet retailing, which do not typically have a significant personal interaction component (between customer and sales staff).

\section{The typical behaviour and expectations of clothing shoppers}

There is ample evidence in the retailing literature that retail store attributes affect store choice and purchase behaviour (Paulins \& Geistfeld, 2003: 371; Hansen \& Deutscher, 1977-1978; Berry, 1986; Leszczyc \& Timmermans, 2001). The appearance of and interaction with salespeople, for instance, are important determinants of whether a female customer will take advice from and return for further purchases (De Klerk, Velleman \& Malherbe, 1998:15-24). A study in South Africa found that physical facilities, the service provided by sales people and store layout are of particular importance to black female clothing shoppers (Kleinhans, Visser, Van Aardt \& Du Preez, 2001:4-15). Torres, Summers and Belleau (2001:207) ascertained that the following five store attributes (in order of most important to least important) are the most important to male shoppers when they shop for clothing:

Price of merchandise

Quality of merchandise

Selection of merchandise

Brands carried in the store

Friendly personnel 
Mahoney and Sternquist (1989:101-111) and Thorpe and Avery (1983:35-41) earlier found that the quality and knowledge of sales personnel are important store attributes for clothing shoppers. Speciality store customers are even willing to travel longer distances and pay higher prices in order to be served by knowledgeable sales personnel (Thorpe \& Avery, 1983). Westbrook (1981:68-85) established that the most influential components of retail satisfaction were satisfaction with stores' sales personnel, special store sales, products/services purchased at the store, store environment and the value-price relationship offered by the store. The studies mentioned above provide some insight as to why middle and higher price clothing shops, in their efforts to entice shoppers to browse and spend time in the shop, use a free-flowing or boutique layout pattern. Such a layout creates a friendly atmosphere in which unplanned or impulse purchases are enhanced (Berman \& Evans, 2001:613). All of the above-mentioned attributes of clothing shops that have been found to be important to consumers are captured by the dimensions of ISE.

\section{The typical behaviour and expectations of supermarket shoppers}

It has to be acknowledged that some shopping tasks are not undertaken by choice (Herrington \& Capella, 1995:13). For instance, shopping for groceries might offer rewarding experiences for some consumers, but for others such shopping is undesirable and boring. Consumers also associate more stress with grocery shopping than other forms of shopping. Aylott and Mitchell (1997:687) identified crowding and queuing as the two major stressors when consumers shop for groceries in supermarkets. Supermarket shoppers, for instance, typically dislike crowding (East, Lomax, Wilson \& Harris, 1994:57); undertake a fair amount of search behaviour (Putrevu \& Lord, 2001:137-138); regard queuing as a bad thing (Bennett, 1998:85); require consistency in service delivery (Hare, Kirk \& Lang, 1999:229) and use service quality as an extrinsic cue in the formation of overall merchandise quality perceptions (Sirohi, McLaughlin \& Wittink, 1998:236). Supermarkets, in their efforts to satisfy customers' need for speed and efficiency, often use the straight (gridiron) layout pattern because it creates an efficient atmosphere and makes shopping and self-service easy. The gridiron layout increases the speed of shopping which, in combination with price, is usually very important to supermarket shoppers (Davies, Goode, Moutinho \& Ogbonna, 2001:40).

Supermarkets have to provide a wide range of quality and variety of products in order to appeal to customers. Research by Sirohi, Mclaughlin and Wittink (1998:240) found that product quality for a supermarket depends on fifteen indicators. These indicators included quality items related to the grocery, bakery, frozen food, meat, health and beauty and other departments of a supermarket which often lead to very complex mixes being offered by grocery retailers.

The image the retailer wishes to project will, to a large extent, determine the merchandise variety and the depth of assortment to be offered. For instance, a supermarket's merchandise variety and assortment, is associated with the customer services and facilities of the supermarket (Bishop
1984; Doyle, 1984). Price as an extrinsic cue is very important to supermarket shoppers as they typically do not regard the time and effort spent in evaluating intrinsic cues as worthwhile (Sirohi et al., 1998:227). Kerin, Jain and Howard (1992:383), for example, suggest that because of the variety of extrinsic cues available in a supermarket (e.g. cleanliness, assortment and variety), price and quality perceptions could co-vary and that consumers 'get what they pay for'.

Against this background of differing consumer expectations and decision-making criteria in different retail environments the purpose of this study was to investigate and quantify the relative influence of these criteria on customer retention for shoppers in two diverse shopping environments, namely supermarkets and clothing retailers. The dependent variable in this study is thus customer retention.

\section{Objectives}

Not all retail store attributes are equally important in affecting store choice. Paulins and Geistfeld (2003: 373), provide a comprehensive list of eighteen store attributes that affect store choice and that have been researched during the past four decades. Based on this review we propose that the relative importance of the five dimensions of ISE will impact differently on outcomes such as cumulative customer satisfaction and loyalty in different retail environments.

The objective of this study is thus to compare the in-store shopping experience of customers in two diverse retailing environments (supermarkets versus clothing retailers) by assessing its impact on customer retention.

In broad terms the following proposition is investigated:

P1: The impact of the five dimensions of the in-store shopping experience on customer retention is not the same in different retailing environments.

\section{Methodology}

\section{Sampling}

The sampling procedure used for the data collection was a combination of convenience and random sampling. The retailers who participated in the study were selected on a convenience basis. The respondents (shoppers) who were surveyed were selected on a random basis. The sample consisted of two sub-samples: customers of a national clothing retailer and customers of a major national grocery supermarket. Eleven branches of the clothing retailer and eight branches of the super retailers were included in the survey. Before the surveys were undertaken, the two retail companies confirmed that the customers patronising the relevant stores, are representative of the national customer profile of their customers. Individual respondents (customers) were selected on a simple random basis by approaching every fourth customer leaving the particular store after shopping. Personal interviews, using a structured questionnaire, were conducted with customers of these stores over a period of two days. Respondents were asked to rate their satisfaction with the retail experience of a 
particular store on a 7-point Likert-type scale. A total of 2 074 clothing shop customers and 1244 supermarket customers were interviewed.

The instrument used in the surveys consisted of 22 items, measuring the following five dimensions: Personal interaction (5 items), Merchandise value (5 items), Merchandise variety (4 items), Internal store environment (5 items), and Complaint handling (3 items). Appendix A contains the items of the instrument used in the survey.

After data capturing the internal reliability of the scale and its dimensions were measured by means of Cronbach Alpha and a confirmatory factor analysis.

\section{Empirical results}

Table 1 shows that the Cronbach alpha co-efficients of the underlying dimensions are well above the generally accepted cut-off value of 0,7 (Peterson, 1994). The reliability co-efficient of the ISE scale when used for supermarket shoppers was 0,951 and 0.949 for clothing store shoppers. One can thus conclude that the ISE instrument is a reliable instrument.
Table 1: Reliability results: cronbach alpha co-efficients

\begin{tabular}{l|c|c}
\hline \multicolumn{1}{c|}{ Dimension } & Supermarket & $\begin{array}{c}\text { Clothing } \\
\text { store }\end{array}$ \\
\hline Personal interaction & 0,872 & 0,866 \\
\hline Merchandise value & 0,838 & 0,837 \\
\hline Complaint handling & 0,821 & 0,793 \\
\hline Internal store environment & 0,861 & 0,847 \\
\hline $\begin{array}{l}\text { Merchandise variety and } \\
\text { assortment }\end{array}$ & 0,864 & 0,843 \\
\hline ISE scale & 0,951 & 0,949 \\
\hline
\end{tabular}

The ISE instrument was then subjected to confirmatory factor analyses to test the measurement model as recommended by Gerbing and Anderson (1988). The results of the confirmatory factor analyses are summarised in Table 2. The RMSEA for both the supermarket sample $(0,035)$ and the clothing store sample $(0,038)$ suggests that the model fits the data closely (Steiger \& Lind, 1980). In addition the absolute fit measures reported in Table 2 meet or exceed the minimum levels normally regarded as cut-off points. For instance, both the LISREL Goodness of Fit Index and the Adjusted Goodness of Fit Index are either very close to or exceed the customary cut-off point of 0,90 , providing additional support for the conclusion that the data fit the theoretical model reasonably well.

Table 2: Fit indices of the ise instrument for supermarkets and clothing stores

\begin{tabular}{|c|c|c|}
\hline Fit indices & Supermarket & Clothing store \\
\hline Degrees of freedom & 199 & 199 \\
\hline Satorra-Bentler scaled chi-square & $508,26(\mathrm{p}=0.0)$ & $809,39(\mathrm{p}=0.0)$ \\
\hline Root mean square error of approximation (RMSEA) & 0,035 & 0,038 \\
\hline 90 Percent Confidence Interval for RMSEA & 0,$032 ; 0,039$ & 0,$036 ; 0,041$ \\
\hline Expected cross-validation index (ECVI) & 0,49 & 0,44 \\
\hline Normed fit index (NFI) & 0,99 & 0,99 \\
\hline Root mean square residual (RMSR) & 0,42 & 0,27 \\
\hline Standardized root mean square residual (SRMSR) & 0,031 & 0,026 \\
\hline Goodness of fit index (GFI) & 0,92 & 0,93 \\
\hline Adjusted goodness of fit index (AGFI) & 0,89 & 0,91 \\
\hline
\end{tabular}

Based on the suggestions of Hair et al. (1998:659) the conclusion can thus be made that the model demonstrates acceptable fit. The next step was thus to assess the empirical model.

\section{An empirical assessment of the ise model in clothing and supermarket shopping environments}

To address the proposition formulated above, the hypothesised relationships between the five ISE dimensions and the dependent variable, namely customer retention, were assessed by means of a structural equation modelling analysis. Retention was measured with a three-item scale. The scale consisted of widely used items to measure satisfaction and loyalty. The Cronbach Alpha values for the retention scale were 0,881 and 0,895 for the supermarket sample and clothing store sample respectively. Figure 2 reveals the differential impact of the different ISE dimensions on customer retention.
In the supermarket sub-sample customer retention is predicted by Merchandise value only $(1,14)$. In the clothing shopping sample customer retention is predicted by Merchandise Value $(0,53)$ but also by Personal Interaction $(0,12)$ and by the prevailing Store Environment $(0,17)$.

Given this differential influence on customer retention Proposition 1 is accepted.

\section{Conclusions}

The only relationship found to be of significance in the supermarket sample, is that of merchandise value. The impact of merchandise value on retention is highly significant. This finding is not surprising, given the high price inflation experienced in food and grocery prices over the past few years. Supermarket consumers are price sensitive and this is clearly illustrated in this study. The insignificant relationship between the other elements of ISE and retention is not surprising. Because time is of the 
essence in supermarket shopping, supermarkets are designed to enhance the efficiency and speed of shopping. Minimum interaction with supermarket personnel takes place. The environment is also not regarded as important as the gridiron layout is the norm. The store variety and assortment offering, one of the most difficult decisions in retailing, is well catered for by the particular supermarket group. They offer, apart from a wide selection of national brands, also their own brands to appeal to both price sensitive shoppers as well as shoppers that prefer specific brands. The supermarket has a toll free customer care number and a refund and replace policy to deal with complaints. Customers thus have ample opportunities for redress.

Three of the five ISE dimensions were found to exert a significant impact on customer retention in the clothing sample. In line with expectations, personal interaction and

\section{SUPERMARKET}

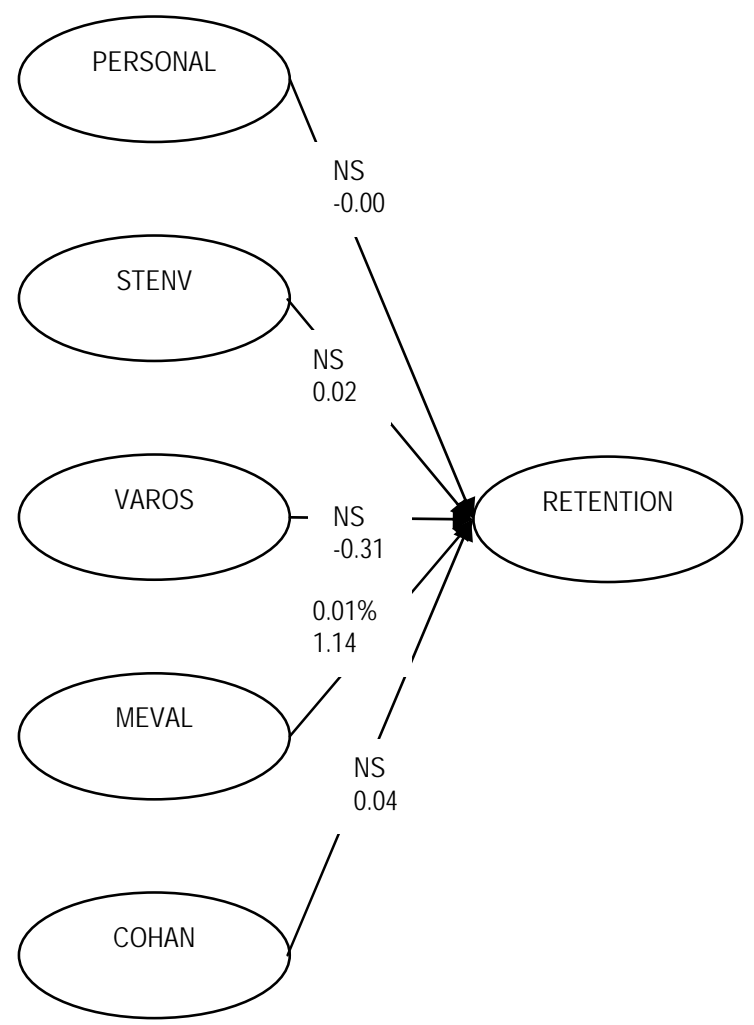

store environment impacted positively on retention with the store environment having the stronger impact of the two. These results confirm the findings of earlier studies where it was found that the store environment and the personal attention and advice of store employees are important to clothing shoppers. The merchandise value dimension, however, impacted strongest on customer retention (significant on the $0,01 \%$ level). This state of affairs can most probably be ascribed to the fact that the clothing retailer in this particular study deals in fashion clothing for the whole family. The importance of value in the shopping decision for especially children's clothing is possibly a major underlying motivation that results in the strong impact of merchandise value on retention. The importance of merchandise value would most probably be less in an exclusive clothing boutique retailer.

\begin{abstract}
Model fit statistics
Satora-Bentler Chi-Square

df

$\mathrm{P}$-value

RMSEA
\end{abstract}

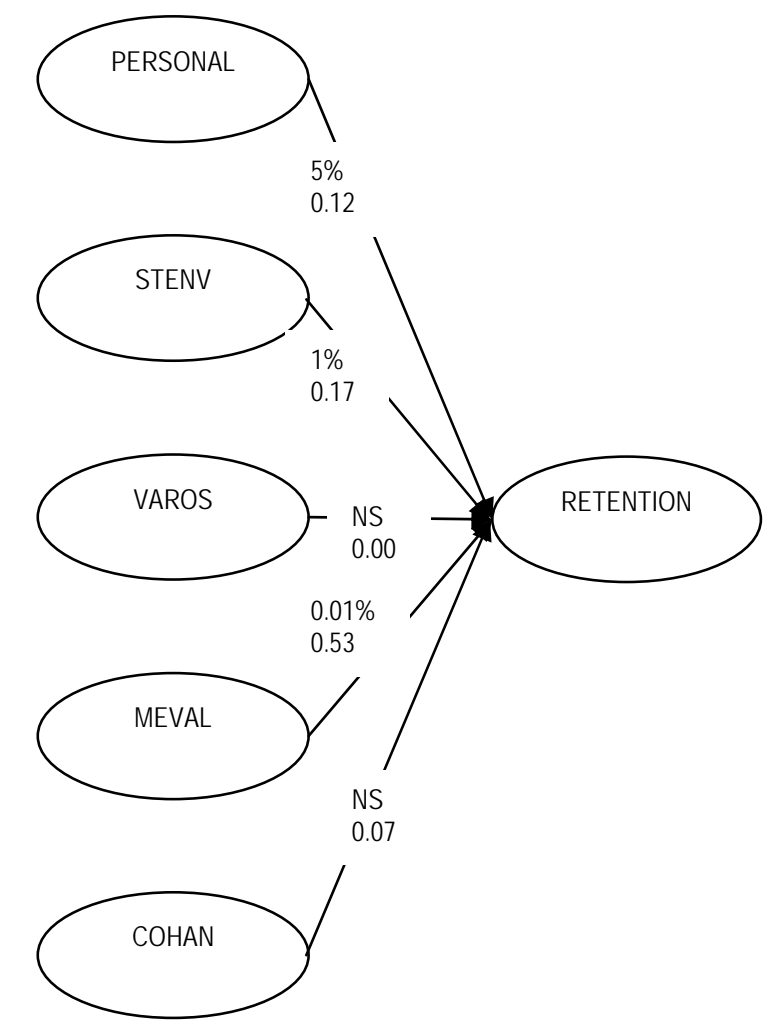

\section{CLOTHING STORE}

\section{Supermarket model}

606,87

260

0,0000

0,033

\section{Clothing store \\ model}

1581,61

260

0,0000

0,050 
Merchandise variety and assortment as well as complaint handling did not impact significantly on retention. The clothing store is well-known for the wide range of fashion and other clothing they offer. Well-known brands are offered and this may be the reason for variety and assortment not being considered as important because customers usually find what they want. The insignificance of complaint handling can also be ascribed to the effective complaint system of the retailer that offers sufficient opportunities to have clothing replaced or returned.

It is important to note that merchandise value had the strongest impact on customer retention, for both the supermarket sample and the clothing sample.

\section{Managerial implications}

Store-based retailers continually experience increasing competition from retail formats such as catalogues, television shopping opportunities, the Internet as well as from one another. New retail formats that develop and become forces in the market place, increasingly compel retailers to be more knowledgeable about the attributes that attract customers to stores. To remain competitive, storebased retailers should be prepared to implement far-reaching changes.

Neither a 'pure' service nor a 'pure' physical goods environment exists in retailing. Instead, consumers rather buy a bundle of benefits that consist of both physical components and service components. The empirical results reported here suggest that a retailer that wishes to enhance the total retailing experience of its customers will have to focus its efforts on all five dimensions of ISE.

Employees who are always willing to help, who provide personal, individualised attention, who are courteous when dealing with customers no matter how 'difficult' or demanding they may seem to be, who respond promptly to requests will enhance customer satisfaction and improve customer retention. The quality of merchandise and the price thereof combine to form value in the consumer's mind and it is therefore imperative that retailers ensure that the components of value are in balance with one another. The physical cues that customers encounter when they enter a retail environment such as the physical store environment (floor covering, lighting, and shelves) and even the appearance of supporting physical equipment such as shopping bags and catalogues exert a significant influence on customer satisfaction. Retailers can, by enhancing perceptions of variety and assortment, enhance customer satisfaction and improve customer retention.

Retailers can obviously differentiate themselves by providing a positive in-store retail shopping experience (ISE) for their customers. The ISE instrument could be useful in the first place to assess the relative influence of the five dimensions on beneficial outcomes such as customer retention. Once these values have been determined they can serve as benchmarks for future comparisons. The ISE values can also be used to compare departments, branches, regions or other entities. The empirical values produced by an ISEbased survey of customers' perceptions would also identify the areas of a retailer's operations that warrant training and other managerial interventions.

\section{Conclusions}

Retailing consists of varied and diverse activities and retail shopping is also varied in terms of the types of products bought. The retail environment is further complicated by the diversity of retail formats such as catalogue retailing and more recently, electronic retailing.

In a retail environment where a mix of goods and services is offered (as is the case in a supermarket and a clothing store), the approach to managing such a store should preferably be all-inclusive (as opposed to focusing on a single dimension such as service) and focus on the management of all the controllable dimensions of the in-store shopping experience. We thus recommend that any measure of customer satisfaction at store level in a retail environment needs to include all five dimensions of the ISE to ensure that the uniqueness of any retail situation can be adequately captured.

\section{References}

Anderson, E. W., Fornell, C. \& Lehmann, D. R. 1994. 'Customer satisfaction, market share, and profitability : Findings from Sweden', Journal of Marketing, 58 (July): 53-66.

Anthanassopoulos, A. D. 2000. 'Customer satisfaction cues to support market segmentation and explain switching behaviour', Journal of Business Research, 47(3):191-207.

Aylott, R. \& Mitchell, V.W. 1998. 'An exploratory study of grocery shopping stressors', British Food Journal, 101(9): 683-700.

Bennett, R. 1998. 'Queues, customer characteristics and policies for managing waiting-lines in supermarkets', International Journal of Retail \& Distribution Management, 26(2): 78-87.

Berman, B. \& Evans, J. R. 2001. Retail management. 8th Edition. Upper Saddle River: Prentice Hall.

Berry, L. L. 1986. 'Retail businesses are service businesses', Journal of Retailing, 62 (Spring): 3-6.

Bishop, W.R. 1984. 'Competitive intelligence', Progressive Grocer, March: 19-20.

Cronin, J. J. (Jr.), Brady, M.K. \& Hult, G. T. 2000. 'Assessing the effects of quality, value, and customer satisfaction on consumer behavioral intentions in service environments', Journal of Retailing, 76(2):193-218.

Dabholkar, P. A., Thorpe, D.I. \& Rentz J. O. 1996. 'A measure of service quality for retail stores: scale development and validation', Journal of the Academy of Marketing Science, 24(1):3-16. 
Darden, W.R., Erdem, O. \& Darden, D. K. 1983. 'A comparison and test of three causal models of patronage intentions'. In Darden, W.R. \& Lusch, R. F. (Eds.). Patronage behavior and retail management. New York : North-Holland.

Davidson, W.R., Sweeney, D.J. \& Stampfl, R.W. 1988. Retail management. 6th Edition. New York: John Wiley \& Sons.

Davies, F.M., Goode, M.M.H., Moutinho, L.A. \& Ogbonna, E. 2001. 'Critical factors in consumer supermarket shopping behaviour: A neural network approach', Journal of Consumer Behaviour, 1(1): 35-49.

De Klerk, H.M., Velleman, A.K. \& Malherbe, E. 1998. “n Kwalitatiewe ondersoek na die invloed van aspekte van die klerewinkel en die verdoopsdame se voorkoms op die damesklereverbruiker se besluitnemingsproses', Journal of Family Ecology and Consumer Sciences, 26(1): 15-26.

Dickson, J. \& Albaum, G. 1977. 'A method for developing tailormade semantic differentials for specific marketing content areas', Journal of Marketing Research, 14(February): 87-91.

Dickson, J.P. \& MacLachlin, D.L. 1990. 'Social distance and shopping behaviour', Journal of the Academy of Marketing Science, 18(2): 153-161.

Donavon, R.J. \& Rossiter, J.R. 1982. 'Store atmosphere: An environmental psychology approach', Journal of Retailing, 58 (Spring): 39-52.

Doyle, M. 1984. 'New ways of measuring value', Progressive Grocer Value, Executive Report: 15-19.

East, R., Lomax, W., Wilson, G., \& Harris, P. 1994. 'Decision making and habit in shopping times', European Journal of Marketing, 28(4): 56-71.

Egan, J. 1999. 'Relationship marketing: A retailing perspective'. Paper presented at the $28^{\text {th }}$ Annual EMAC Conference, Berlin, Germany.

Finn, A. \& Kayandé, U. 1997. 'Consistency of the relationship between retailer product and service quality.' Paper read at the $4^{\text {th }}$ Recent Advances in Retailing and Services Science Conference, Scottsdale, Arizona.

Greenley, G.E. \& Shipley, D.D. 1988. 'An empirical overview of marketing by retailing organisations', Service Industries Journal, 8(1): 49-66.

Gutman, J., \& Alden, S.D. 1985. 'Adolescents' cognitive structures of retail stores and fashion consumption: A means-end chain analysis of quality.' In Jacoby, J. \& Olsen, J. (Eds.). Perceived quality: How consumers view stores and merchandise. Lexington, M.A: Lexington Books.

Hair, J. F. (Jr.), Anderson, R.E., Tatham, R. L. \& Black, W. C. 1998. Multivariate data analysis. 5th Edition. Upper Saddle River: Prentice Hall.
Hallowell, R. 1996. 'The relationship of customer satisfaction, customer loyalty and profitability: an empirical study', The International Journal of Service Industry Management, 7(4): 27-42.

Hansen, H. \& Deutscher, T. 1977/87. 'An empirical investigation of attribute importance in retail store selection', Journal of Retailing, 53(4): 59-72 \& 95.

Hare, C., Kirk, D., \& Lang, T. 1999. 'Identifying the expectations of older food consumers : More than a 'shopping list' of events', Journal of Marketing Practice: Applied Marketing Science, 5(6/7/8): 213-232.

Hasty, R. \& Reardon, J. 1997. Retail management. New York: McGraw-Hill.

Herrington, J.D. \& Capella, L.M. 1995. 'Shopper reactions to perceived time pressure', International Journal of Retail and Distribution Management, 23(12): 13-20.

Hummel, J.W. \& Savitt, R. 1988. 'Integrated customer service and retail strategy', International Journal of Retailing, 3(2): 5-21.

Kerin, R. A., Jain, A. \& Howard, D.J. 1992, 'Store shopping experience and consumer price-quality-value perceptions', Journal of Retailing, 68 (4):376-397.

Kleinhans, E.H., Visser, E.M., Van Aardt, A.M. \& Du Preez, R. 2001. 'Black female consumers' perception of apparel store image'. Paper read at the SAAFECS National Congress, Pretoria.

Leszczyc, P.T.L.P. \& Timmermans, H. 2001. 'Experimental choice analysis of shopping strategies', Journal of Retailing, 77(4): 493-509.

Mahoney, M.Y. \& Sternquist, B. 1989. 'Perceptions of the discount retailer: an analysis of consumers' and managers' ideal discount store', Journal of Consumer Studies and Home Economics, 13: 101-111.

Mazursky, D. \& Jacoby, J. 1985. 'Forming impressions of merchandise and service quality’. In Jacoby, J. \& Olsen, J. (Eds.). Perceived quality: How consumers view stores and merchandise. Lexington, M.A: Lexington Books.

Oliver, R. 1981. 'Measurement and evaluation of satisfaction processes in retail settings', Journal of Retailing, 57(Fall): 25-48.

Parasuraman, A., Zeithaml, V. A. \& Berry, L. L. 1988. 'SERVQUAL: A multiple-item scale for measuring consumer perceptions of service quality', Journal of Retailing, 64(1): 12-40.

Paulins, V.A. \& Geistfeld, L.V. 2003. 'The effect of consumer perceptions of store attributes on apparel store preference', Journal of Fashion Marketing and Management, 7(2): 371-385. 
Peterson, R.A. 1994. ‘A meta-analysis of Cronbach's coefficient alpha', Journal of Consumer Research, 27: 381391.

Petrevu, S. \& Lord, K.R. 2001. 'Search dimensions, patterns and segment profiles of grocery shoppers', Journal of Retailing and Consumer Services, 8(3): 127-137.

Reichheld, F. F. \& Sasser, W.E. 1990. 'Zero defections: Quality comes to service', Harvard Business Review, 68(5): 105-111.

Ridgeway, N.M., S.A. Dawson \& Bloch, P.H. 1989. 'Pleasure and arousal in the marketplace: interpersonal differences in approach-avoidance responses', Marketing Letters, 1(2): 139-147.

Sirohi, N., McLaughlin, E.W. \& Wittink, D.R. 1998. 'A model of consumer perceptions and store loyalty intentions for a supermarket retailer', Journal of Retailing, 74(2): 223245.

Sopanen, S. 1996. Customer loyalty schemes in retailing across Europe. Oxford Reports on Retailing, Oxford Institute of Retail Management.

Steiger, J. H. \& Lind, J. C. 1980. 'Statistically based tests for the number of common factors'. Paper presented at the Annual Meeting of the Psychometric Society, Iowa City, IA.

Terblanche, N.S. \& Boshoff, C. 2003. 'A generic instrument to measure customer satisfaction with the controllable elements of the in-store shopping experience'. Paper presented at the $32^{\text {nd }}$ Annual EMAC Conference, Glasgow, Scotland.

Torres, I.M., Summers, T.A. \& Belleau, B.D. 2001. 'Men’s shopping satisfaction and store preferences', Journal of Retailing and Consumer Services, 8(4): 205-212.

Thorpe, D.I. \& Avery, C.E. 1983. 'A demographic and psychographic assessment of a specialty store’s customers and non customers', Clothing and Textiles Research Journal, 2: 35-41.

Van Herpen, E. \& Pieters, R. 2000. 'The variety offered by stores'. Paper presented at the $29^{\text {th }}$ Annual EMAC Conference, Rotterdam, The Netherlands.

Vásquez, R., Rodriques-del Bosque, I.A., Díaz, A.M. \& Ruiz, A.V. 2001. 'Service quality in supermarket retailing: identifying critical service experiences', Journal of Retailing and Consumer Services, 8(1): 1-14.

Westbrook, R.A. 1981. 'Sources of consumer satisfaction with retail outlets', Journal of Retailing, 57(Fall): 68-85. 
APPENDIX A

ITEMS TO MEASURE THE IN-STORE RETAIL SHOPPING EXPERIENCE (ISE) OF CUSTOMERS

\begin{tabular}{l}
\hline Merchandise value \\
\hline XYZ's products are of good quality \\
\hline Prices at XYZ store offer value for money \\
\hline XYZ's products function the way they are supposed to \\
\hline XYZ's product prices represent good value \\
\hline XYZ's products are free from defects and flaws \\
\hline Internal Store Environment \\
\hline XYZ has attractive décor \\
\hline XYZ has attractive physical facilities (check-out counters, shelves, etc) \\
\hline XYZ has attractive product and promotional displays \\
\hline XYZ has attractive materials associated with their service (shopping bags, catalogues, etc) \\
\hline XYZ has well-spaced product displays \\
\hline Personal interaction \\
\hline XYZ's staff give me personal attention \\
\hline XYZ's staff are always willing to help me \\
\hline XYZ's staff provide me with prompt service \\
\hline XYZ's staff are courteous \\
\hline XYZ's staff are never too busy to assist me \\
\hline Merchandise variety \\
\hline XYZ offers a choice of different brand names \\
\hline XYZ offers a good selection of well-known brands \\
\hline XYZ offers a variety of brand names that are available in many different sizes \\
\hline XYZ offers a wide variety of products \\
\hline Complaint handling \\
\hline XYZ has an effective means of dealing with customer complaints \\
\hline XYZ has a fair system for the handling of complaints \\
\hline XYZ staff efficiently deal with customer complaints
\end{tabular}

